\title{
APLIKASI PEMBAYARAN TAGIHAN AIR PADA PAMSIMAS KKM BENING LESTARI DESA ALAI SELATAN
}

\author{
Yenni Herayani \\ Manajemen Informatika, AMIK Selat Panjang, Jalan Terpadu Dorak No. 100 Selat Panjang \\ email: yenniherayani280181@gmail.com
}

\begin{abstract}
The Water Bill Payment System that runs on PAMSIMAS KKM Bening Lestari in South Alai Village is still manual using the payment book, which results in the non-optimal performance of the Water Service Manager in The Alai Village.The weakness of the current system is that there is no control over the delay of residents in paying water bills,officers have difficulty when officers or residents want to know the history of the amount of debit used by resident previous month,This study use Prototype Methods to solve existing problems so as to produce a Water Bill Payment Application that can find out the amount of the fine in accordance with the delay of residents paying water bills.
\end{abstract}

Keywords: Application,Water Bill Payment,Prototype Methods.

\begin{abstract}
Abstrak
Sistem Pembayaran Tagihan air yang berjalan pada PAMSIMAS KKM Bening Lesteri Desa Alai Selatan masih manual dengan menggunakan buku pembayaran,hal tersebut mengakibatkan belum optimalnya kinerja dari pengelola Layanan Air di desa Alai tersebut. Kekurangan dari sistem yang sedang berjalan ini adalah tidak adanya kontrol terhadap keterlambatan warga dalam membayar tagihan air,petugas mengalami kesulitan ketika petugas atau warga ingin mengetahui history jumlah debit yang digunakan warga pada bulan sebelumnya.Penelitian ini menggunakan metode Prototype untuk memecahkan permasalahan yang ada sehingga menghasilkan sebuah Aplikasi Pembayaran Tagihan Air yang dapat mengetahui berapa pemakaian serta jumlah denda sesuai dengan keterlambatan warga yang membayar tagihan air.
\end{abstract}

Kata Kunci: Aplikasi,Pembayaran Tagihan Air,Metode Prototype.

\section{PENDAHULUAN}

PAMSIMAS (Penyediaan Air Minum Dan Sanitasi Berbasis Masyarakat) adalah pelayanan penyediaan air dan sanitasi bagi masyarakat. Penyediaan prasarana dan sarana air minum dan sanitasi yang baik akan memberi dampak pada peningkatan kualitas lingkungan dan kesehatan masyarakat, serta waktu yang dapat dihemat dari usaha untuk mendapatkan air minum dan sanitasi yang baik. Ketiga dampak tersebut akan memberikan dampak lanjutan berupa peningkatan produktifitas masyarakat.

Berdasarkan hasil penelitian dan analisis kebutuhan yang penulis lakukan pada Kantor PAMSIMAS KKM Bening Lestari di desa Alai Selatan, sistem pengelolaan pembayaran tagihan air dan pengeloalaan data pelanggan masih dilakukan dengan cara mencatat di buku. Jika ditinjau dari efektifitas kinerja masih belum efektif, karena sering terjadinya kesalahan dalam pembayaran jumlah tagihan dan membutuhkan waktu yang lama dalam pencarian data pelanggan dikarenakan banyaknya jumlah pelanggan. 
Adapun tujuan dari penelitian ini yaitu untuk membantu pihak PAMSIMAS KKM Bening Lestari di Desa Alai Selatan khususnya bagian pembayaran pelanggan serta meningkatkan pelayanan kepada pelanggan. Manfaat yang diperoleh dalam penelitian ini adalah petugas atau pelanggan dapat melihat berapa jumlah pemakaian maupun jumlah denda yang harus dibayarkan sesuai dengan keterlambatan .

\section{METODE PENELITIAN}

Metode penelitian yang digunakan oleh penulis dalam penelitian ini adalah

1. Metode Pengumpulan Data

Metode pengumpulan data yang digunakan dalam penelitian ini adalah sebagai berikut :

a. Metode Observasi

Peneliti melakukan pengamatan langsung terhadap permasalahan yang terjadi pada PAMSIMAS KKM Bening Lestari di Desa Alai Selatan.

b. Metode Wawancara

Metode ini dilakukan dengan cara melakukan tanya jawab dengan pengguna aplikasi yaitu bagian pembayaran pelanggan pada PAMSIMAS KKM Bening Lestari di Desa Alai Selatan.

\section{Metode Analisis}

Setelah pengumpulan data dilakukan melelui beberapa teknik ,maka data tersebut akan dianalisis guna memperoleh informasi yang berguna dalam penelitian ini.

\section{Metode Pembuatan Prototype}

a. Perancangan Model

Perancangan Model yang digunakan dalam penelitian ini adalah dengan menggunakan Diagram Konteks dan Data Flow Diagram(DFD). b. Bahasa Pemograman

Pada penelitian ini,penulis membuat aplikasi dengan menggunakan bahasa pemograman $\operatorname{PHP}($ Hypertext Processor),pembuatan database dengan $M y S Q L$,editor untuk pembuatan aplikasi yaitu dengan Notepad ++,desain menggunakan aplikasi Adobe Dreamweaver dan aplikasi penghubung yang menghubungkan $P H P$ dan $M y S Q L$ dengan Xampp.

\section{HASIL DAN PEMBAHASAN}

Untuk mendapatkan hasil diinginkan pengguna,maka penulis melakukan tahapan yaitu :

1. Perancangan model penelitian ini dengan menggunakan Diagram Konteks, Data Flow Diagram (DFD) sebagai berikut :

Hasil Perancangan nya antara lain :

a. Diagram Konteks

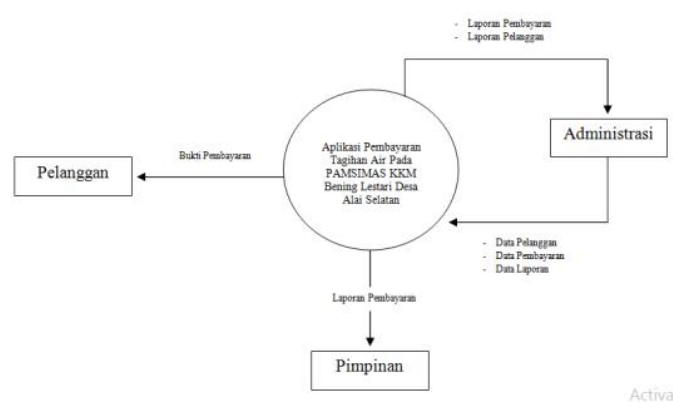

\section{Gambar 1 : Diagram Konteks Sumber : Yenni Herayani}

Penjelasan dari Gambar 1 adalah, Admin dapat melakukan proses input, update, delete dan view data pelanggan pada aplikasi pembayaran tagihan air serta melakukan perubahan biodata terhadap pelanggan. Setelah admin melakukan proses input data, maka pimpinan bisa melihat laporan pelanggan dan juga admin bisa mencetak laporan data pelanggan dan laporan pembayaran. 
b. Data Flow Diagram Level 0

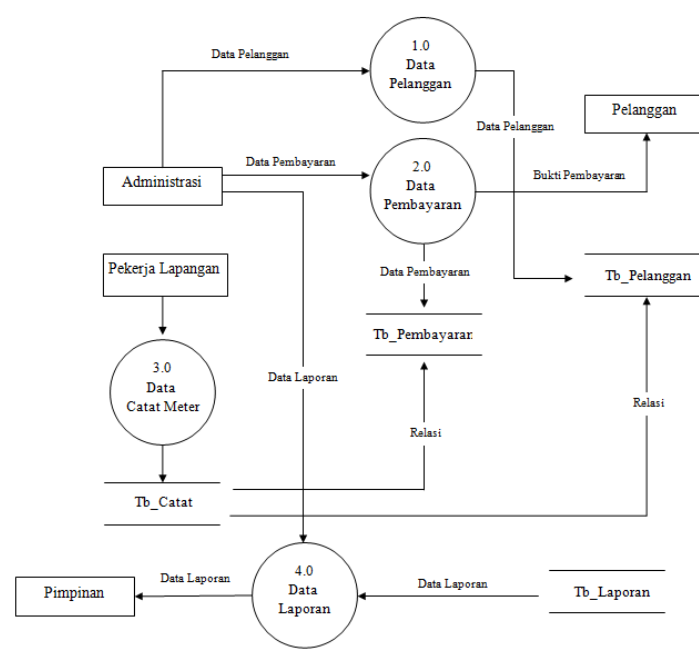

\section{Gambar 2 : Data Flow Diagram Level 0 Sumber : Yenni Herayani}

Penjelasan dari Gambar 2 adalah, proses pertama yang dilakukan oleh Admin PAMSIMAS KKM Bening Lestari Desa Alai Selatan yaitu dengan menginput data pelanggan sesuai dengan data yang ada di KTP dan nantinya akan tersimpan di tabel pelanggan. Selanjutnya admin mengiput data pembayaran pelanggan ke tabel pembayaran.Setelah selesai memasukkan data pembayaran pelanggan setelah itu admin akan mencetak laporan pelanggan dan laporan pembayaran diserahkan ke pimpinan.

\section{Hasil Perancangan Program}

\section{a. Desain Menu Login Admin}

Pada gambar ini merupakan tampilan dari menu login admin,untuk bisa masuk ke menu area untuk mengolah menu aplikasi transaksi.

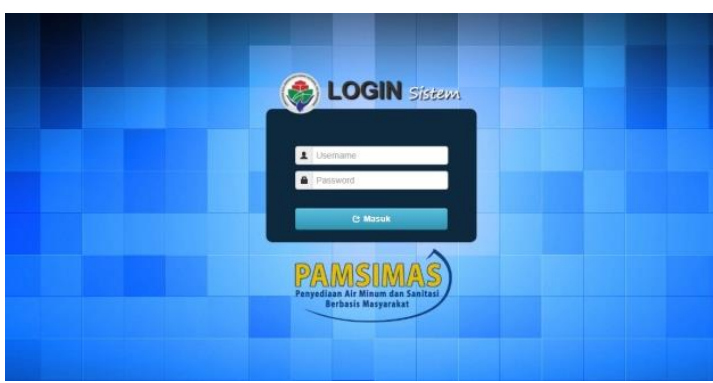

Gambar 3 : Tampilan Menu Login

\section{Sumber : Yenni Herayani}

\section{b. Tampilan Home Area}

Merupakan menu yang berfungsi sebagai menu area admin yang terdapat link menu untuk aplikasi pembayaran.

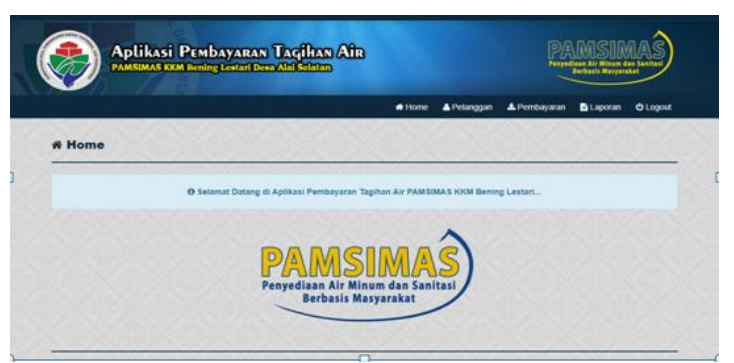

Gambar 4 : Tampilan Home Area Sumber : Yenni Herayani

\section{c.Desain Tampilan Menu Pelanggan}

Pada tampilan menu pelanggan ini berfungsi untuk melihat data pelanggan

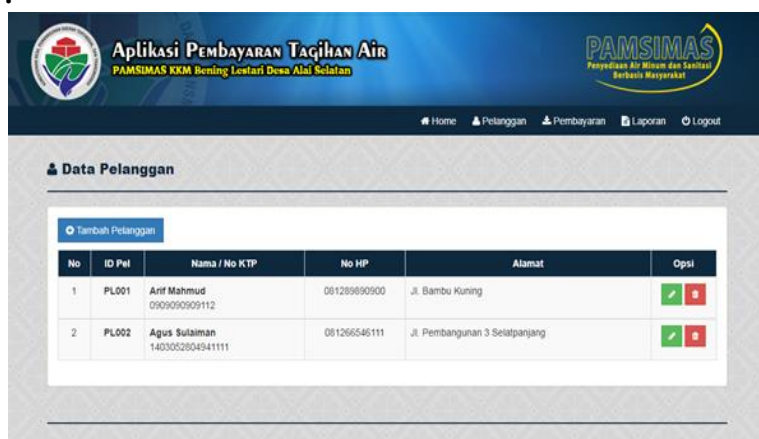

Gambar 5 : Tampilan Menu Pelanggan

Sumber : Yenni Herayani

\section{d. Desain Tampilan Menu Tambah Data Pelanggan}

Menu ini berisikan beberapa link untuk menginput data baru pelanggan yang melakukan pendaftaran dan proses penginputan sesuai dengan data yang ada di KTP.

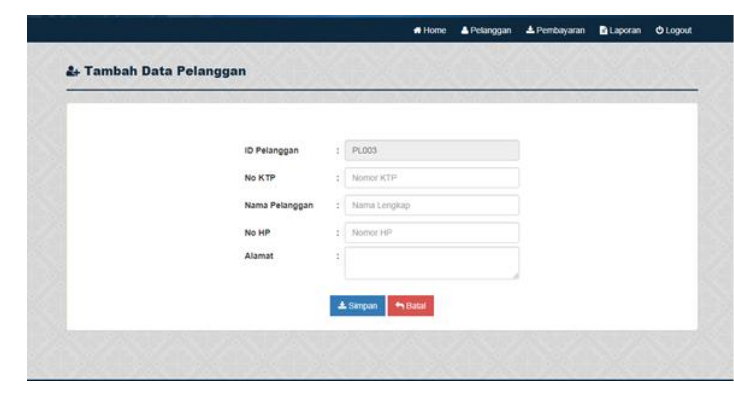




\section{Gambar 6 : Tampilan Menu Tambah Pelangaan Sumber : Yenni Herayani}

\section{e. Desain Tampilan Menu Cari Tagihan}

Pada Menu ini digunakan oleh admin untuk mencari data tagihan pelanggan,sehingga admin bisa lebih cepat mengeceknya.

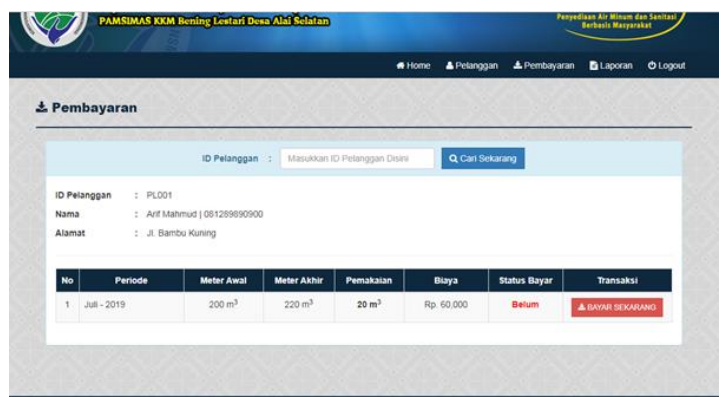

Gambar 7 : Tampilan Menu Cari Tagihan Sumber : Yenni Herayani

\section{f. Desain Tampilan Menu Pembayaran} Menu ini berisikan tampilan tentang berapa jumlah tagihan yang harus dibayarkan serta denda jika mengalami keterlambatan pembayaran.

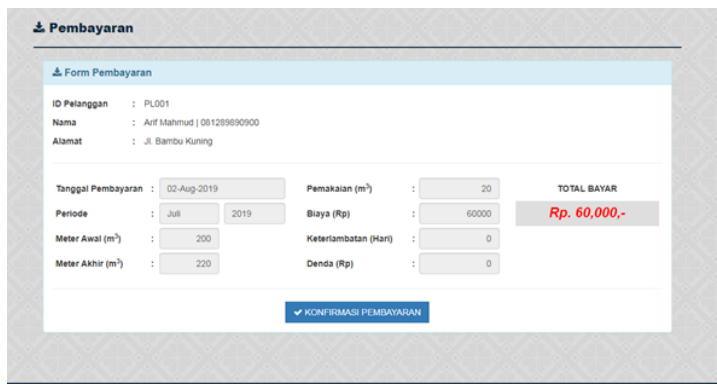

Gambar 8 : Tampilan Menu Pembayaran Sumber : Yenni Herayani

\section{g.Tampilan Menu Laporan}

Pada menu ini dapat dilakukan pencetakan laporan oleh admin yaitu laporan data pelanggan.

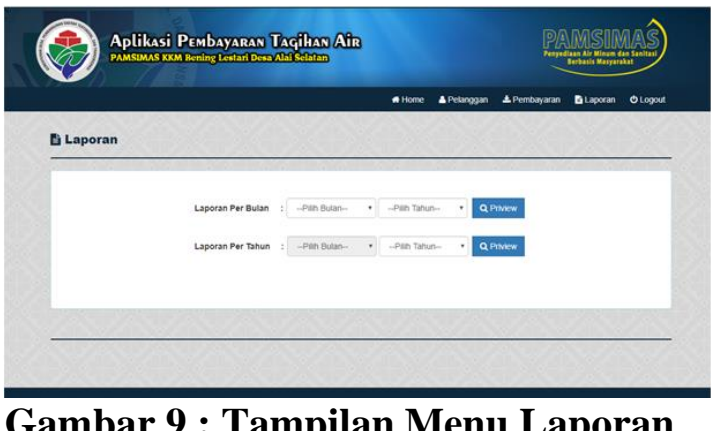

Gambar 9 : Tampilan Menu Laporan Sumber : Yenni Herayani

\section{SIMPULAN}

Berdasarkan hasil penelitian dan pengamatan yang telah penulis lakukan maka didapatkan beberapa kesimpulan yaitu sebagai berikut :

1. Sistem pembayaran tagihan air yang sudah berjalan di PAMSIMAS KKM Bening Lestari Desa Alai Selatan dilakukan secara komputerisasi dengan aplikasi yang sudah dibangun dan sistem pelayanan untuk pembayaran tagihan air pelanggan akan lebih efektif dengan waktu yang cepat dalam pencarian data pelanggan,tagihan,pembayaran serta denda.

2. Dengan adanya aplikasi ini dapat memudahkan pengguna(user)dalam membuat laporan pembayaran serta laporan pelanggan tepat waktu.

\section{UCAPAN TERIMAKASIH}

Penelitian ini dapat terlaksana dengan baik atas dukungan banyak pihak, untuk itu diucapkan terima kasih kepada : Pengelola PAMSIMAS KKM Bening Lestari Desa Alai Selatan Kecamatan Tebing Tinggi Barat Kabupaten Kepulauan Meranti.

\section{DAFTAR PUSTAKA}

Suhartini,2017 Analisis dan Pengembangan Aplikasi Pembayaran Studi Kasus 
Perusahaan Daerah Air Minum (PDAM) Tirta Prabujaya Kota Prabumulih. Volume 8, Nomor 1.

Magdalena,Lena.Hatta,Muhammad,Natalia, Lisa 2018.Pengembangan Aplikasi Pencatatan Transaksi Biaya Kuliah STMIK CIC Cirebon ,Jurnal DIGIT,Vol 6, No.1.

Kurniawan, Yohanes,Christie

Parapaga,Janasta 2014.

Pengembangan Sistem Informasi Siklus Pendapatan Pada PT.XYZ (Pendekatan Studi Kasus). Ultima InfoSys, UMI. Vol. V, Nomor 1.

Ni Putu Neni Purwanti.dkk 2014.

Analisis Kualitas Pelayanan Pada Perusahaan daerah Air Minum(PDAM) Kota Denpasar,ejournal.undiksha.ac.id,V ol 4,No.1 